\title{
WHAT IS THE RIGHT THERAPEUTIC APPROACH TO BILIARY CHOLEDOCHAL CYST?
}

\author{
Marinko Marušić ${ }^{1,3}$, Anto Dominković ${ }^{1}, Z_{\text {eljka Belošić Halle }}^{1,3}$, Rosana Troskot Perić ${ }^{1,3}$, \\ Ivan Zoričić ${ }^{2,3}$, Darko Vukušić ${ }^{2}$ and Ana Marija Liberati Čizmek ${ }^{1}$
} ${ }^{1}$ Clinical Department of Internal Medicine, ${ }^{2}$ Clinical Department of Surgery, Sveti Duh University Hospital,
Zagreb; ${ }^{3}$ School of Medicine, Josip Juraj Strossmayer University of Osijek, Osijek, Croatia

\begin{abstract}
SUMMARY - We report a case of biliary cyst type II which, independently of its a priori benign nature, caused numerous complications such as recurrent cholangitis and pancreatitis, as well as subsequent hepatic fibrosis and the potential danger of choledochocele perforation. Although they are benign, biliary/choledochal cysts can cause numerous disorders such as cholestasis, leading to cholangitis and pancreatitis and biliary sepsis, and due to chronic inflammation of the biliary system even cholangiocarcinogenesis. Our findings showed that sometimes this type of biliary cyst (according to the available literature the rarest and most benign type), as well as type I cyst, should undergo timely radical excision. In our patient, timely choledochocele resection would have certainly contributed to the reduction of subsequent complications, as well as to obviating repeated invasive diagnostic and surgical procedures.
\end{abstract}

Key words: Biliary tract diseases - therapy; Cholangitis; Pancreatitis; Bile ducts - surgery; Case reports

\section{Introduction}

Biliary trunk cysts are a rare disorder/anomaly of the biliary system with a prevalence of 1 per $100,000-$ 150,000 in western countries, occurring more frequently in females ( $\mathrm{F}: \mathrm{M}=4: 1)$. Even though they are most often revealed in childhood, thanks to the growing number of diagnostic possibilities/imaging techniques, they are becoming more frequently diagnosed in adulthood, when they are often presented with serious clinical features that include vomiting, recurrent abdominal pain, cholangitis and pancreatitis. Although they are a priori benign, biliary/choledochal cysts can cause numerous disorders such as cholestasis, recurrent cholangitis and pancreatitis and biliary sepsis, and due to chronic inflammation of the biliary system even

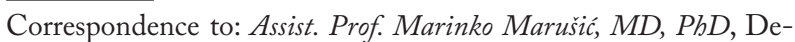
partment of Gastroenterology, Clinical Department of Internal Medicine, Sveti Duh University Hospital, Sveti Duh 64, HR10000 Zagreb, Croatia

E-mail: marinko.marusic1@zg.t-com.hr

Received October 5, 2015, accepted November 25, 2015 cholangiocarcinogenesis. In the case of our patient with an acquired type II biliary cyst (the rarest and most benign type according to the available literature), we encountered recurrent biliary pathology.

\section{Case Report}

In a 55-year-old female patient, dilatation of ductus choledochus was observed during general checkup in 2010 (abdominal ultrasound scan). Until then she had no subjective or clinical symptoms. During hospital treatment in the same year, dilatation of ductus choledochus, $22 \mathrm{~mm}$ of the papilla of Vater with concrements within the lumen and aerobilia was verified, along with a $4-\mathrm{cm}$ cystic formation covering ductus choledochus. At that time, it was not clear whether it was an anatomical anomaly or a low-lying gallbladder filled with concrements compressing the choledochus or choledochocele with concrements. The patient was hospitalized again in July 2010 for additional evaluation of the biliary pathology. Choledocholithiasis was verified and a large choledochal cyst (approximately 5 


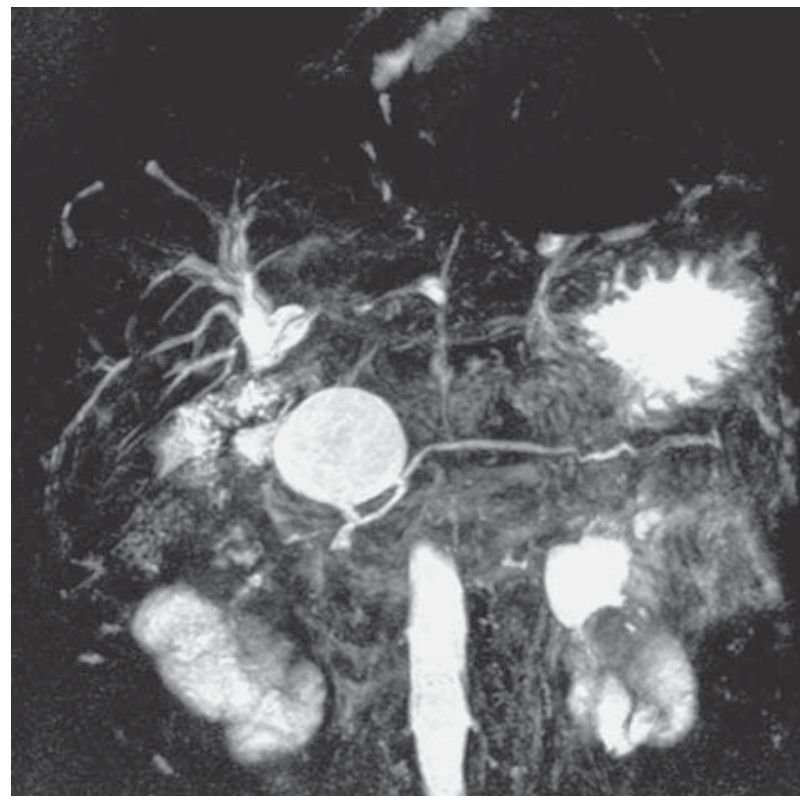

Fig. 1. Magnetic resonance cholangiopancreatography performed during first hospitalization.

$\mathrm{cm}$ in size) stretching throughout the entire duodenal bend behind the head of the pancreas was found. On July 20, 2010, cholecystectomy was performed and 6 large concrements were extracted from the choledochus with creation of Roux-en-Y biliodigestive anastomosis (anastomosis at the level of the proximal common hepatic duct with jejunal loop). The preoperative and early postoperative period was uneventful.

One year after the surgery, the patient experienced recurrent pancreatitis and cholangitis, for which she received repeated conservative hospital treatment (with combined antibiotic and other supportive care). The last hospitalization, prior to arrival to our hospital, was in March 2014.

Upon admission to our hospital on May 28, 2014, the patient suffered severe pain in the upper abdomen accompanied by nausea, chills and shivers. Laboratory findings showed an increase in inflammatory parameters (white blood cell count, C-reactive protein and erythrocyte sedimentation rate), alanine transaminase, aspartate aminotransferase, gamma-glutamyl transpeptidase, lactate dehydrogenase, alkaline phosphatase and urine amylase, and reduction in total proteins, albumin and platelets.

During hospitalization, abdominal ultrasound scan, magnetic resonance cholangiopancreatography (Fig. 1) and endoscopic retrograde cholangiopancrea- tography (ERCP) (Fig. 2) were preformed, which verified choledochal cyst of the distal part of the choledochus, of approximately $4 \mathrm{~cm}$ in size, with its top communicating with the small intestine.

After conducting combined antibiotic therapy (ciprofloxacin + metronidazole) and other supportive measures (proton pump inhibitors, antispasmodics, analgesics, use of crystalloid solutions), the patient showed clinical improvement and the inflammatory and biliary parameters returned to normal. Before discharge from the hospital, the patient was scheduled for surgery.

On July 22, 2014, termino-lateral biliodigestive anastomosis was performed in one act. The preoperative and postoperative period passed without any problems. Numerous fibrous adhesions were verified intraoperatively, as well as stenosis of the previous anastomosis, sludge and lithiasis of the greatly distended hepaticus, and stagnant liver of solid consistency. In fact, the change that was thought to be part of the choledochocele actually was part of the jejunal anastomosis. After successful surgery and postoperative recovery, the patient was discharged from the hospital on August 6, 2014 in good clinical condition.

However, on August 12, 2014, the patient developed fever with an increase in inflammatory and hepatobiliary parameters and was re-hospitalized at our department. Ultrasound of the abdomen showed ductus choledochus of hyperechoic wall and enlarged spleen, along with pre-existing aerobilia of the bile ducts. Chest x-ray showed elevated right diaphragm and hypertonic heart. Multi-slice computed tomography with contrast of the abdomen revealed a cystic structure with a gas-fluid level, $40 \mathrm{~mm}$ in diameter, in the head of the pancreas, which might correspond to the previously discovered choledochus cyst. It did not interfere with bowel movement, movement of free liquids, other pathologic lesions and lymphadenopathy (Fig. 3).

Blood cultures remained sterile, but antibiotic treatment was still administered (ciprofloxacin + metronidazole), soon after which the symptoms subsided and laboratory parameters normalized. The patient was advised to frequently perform inflammation and liver tests, tests for serum and urine amylase, as well as ultrasound examinations. Considering the newly discovered choledochus cyst and involvement of the head of the pancreas, the possibility of cephalic pancreatico- 

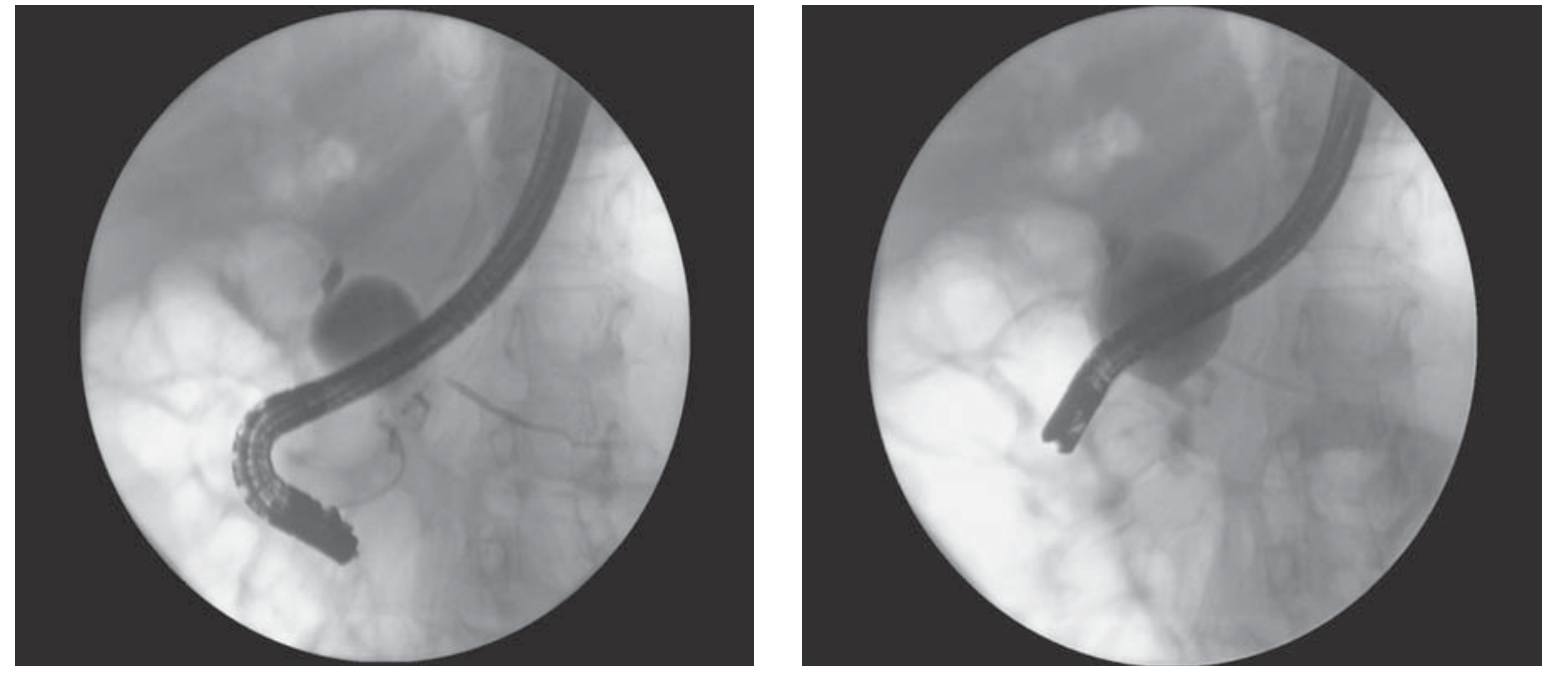

Fig. 2. Endoscopic retrograde cholangiopancreatography performed in July 2014.

duodenectomy arose. The patient is currently in good state both clinically and subjectively, and laboratory findings are satisfactory. Should there be exacerbation of the disease, the findings will be re-evaluated, ERCP and liver biopsy (to accurately determine liver damage) repeated, and surgery, i.e. cephalic pancreaticoduodenectomy, performed.

\section{Discussion}

Although they have a low prevalence, biliary trunk cysts are still an intriguing clinical problem. Recurrent cholangitis, pancreatitis and malignant alteration are major problems that require timely diagnosis and appropriate surgery.

According to Todani et al., biliary cysts are classified into the following types: Ia - dilatation of the extrahepatic bile duct (entire); Ib - dilatation of the extrahepatic bile duct (focal segment); Ic - dilatation of the common bile duct portion of extrahepatic bile duct; II - bile duct diverticulum (rarest, with a prevalence of $0.8 \%-5 \% 1$ ); III - choledochocele, i.e. protrusion of a focally dilated, intramural segment of the distal common bile duct into the duodenum; IVa combination of intra- and extrahepatic cysts; IVb multiple extrahepatic biliary cysts; and V - multiple intrahepatic cysts (Caroli disease) ${ }^{7}$.

Even though our patient had a biliary type II cyst which, like type III, has a low malignant alteration potential and does not require complete excision ${ }^{2,3}$, in

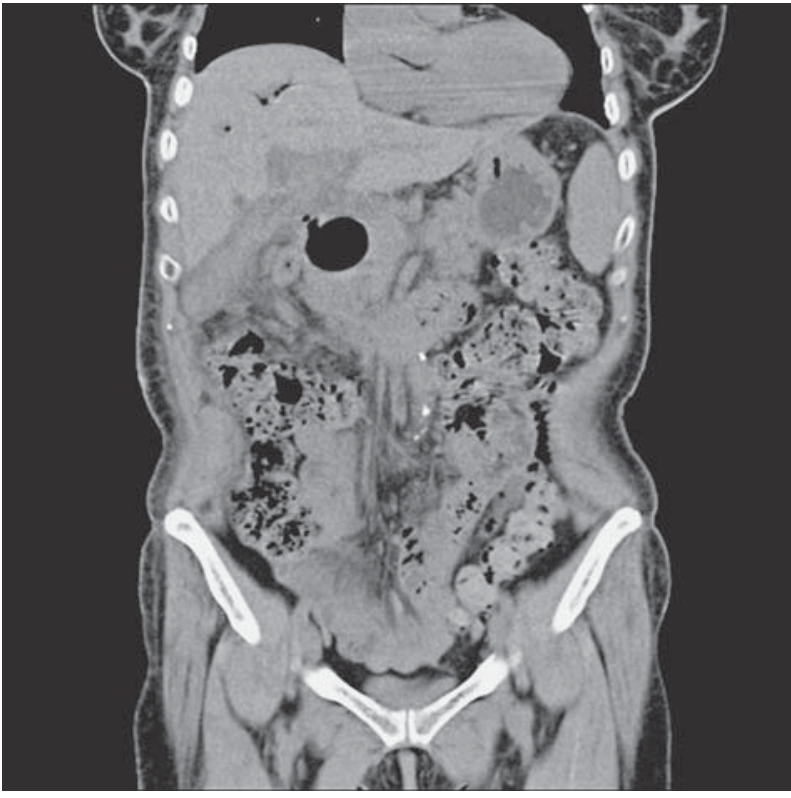

Fig. 3. Multi-slice computed tomography of the abdomen performed with contrast.

this case optimal approach as in case of type I cysts, i.e. timely radical excision, would reduce further complications $s^{3,4}$. Our patient underwent surgery in 2010 because of cholecystolithiasis, cholelithiasis and choledochal cyst. Cholecystectomy was performed and a biliodigestive anastomosis (Roux-en-Y) formed, a procedure with a $92 \%$ success rate ${ }^{5}$ and low complication rate (7\% compared with hepaticoduodenostomy ${ }^{6}$. 
However, even hepaticojejunostomy, which successfully solves the problem of extrahepatic biliary obstruction, in 7\%-38\% of patients can result in anastomotic strictures which require subsequent percutaneous, transhepatic or endoscopic dilation. Further complications include ascending colonization of normally sterile bile ducts by enteral Escherichia coli bacteria, which leads to recurrent cholangitis, biliary lithiasis, pancreatitis, liver failure and cholangiocarcinoma (in $9 \%-28 \%$ of cases $^{7}$ ), or even the formation of peptic ulcers $^{7-12}$.

One of the stages in the liver failures described is periportal fibrosis, which was most likely present in our patient (as suggested by the intraoperative findings of the macroscopically altered liver specimen). Since biliary infection control as one of the three basic preconditions for radical resection/excision of the choledochocele could not be ensured at that time, only Rouxen- $Y$ anastomosis, resection of the part of the ileum, removal of sludge and biliary stones, and creation of a new anastomosis were performed.

\section{Conclusion}

Timely choledochocele resection in our patient would have certainly contributed to the reduction of complications that followed, i.e. recurrent cholangitis and pancreatitis. Also, subsequent hepatic fibrosis and the potential danger of choledochocele perforation could have been avoided.

\section{References}

1. Ouaïssi M, Mehdi KR, Belghiti J, et al. Todani type II congenital bile duct cyst: European Multicenter Study of the French Surgical Association and literature review. Ann Surg. 2014 Jun 27. Epub 2014 Jun 27.
2. Lipsett PA, Pitt HA Surgical treatment of choledochal cysts. J Hepatobiliary Pancreat Surg. 2003;10(5):352-9. http.//dx. doi.10.1007/s00534-002-0797-4

3. Liu DC, Rodriguez JA, Meric F, Geiger JL. Laparoscopic excision of a rare type II choledochal cyst: case report and review of the literature. J Pediatr Surg. 2000 Jul;35(7):1117-9. http:// dx.doi.org/10.1053/jpsu.2000.7840

4. Kirimlioglu V, Yilmaz S, Katz DA, Hilmioglu F, Caglikulekci M, Kayaalp C, Akoglu M, Aksoy F. Choledochal cyst spontaneously rupturing the hepatic artery. Dig Dis Sci. 2000 Mar; 45(3):544-8.

5. Tao KS, Lu YG, Wang T, Dou KF. Procedures for congenital choledochal cysts and curative effect analysis in adults. Hepatobiliary Pancreat Dis Int. 2002 Aug;1(3):442-5.

6. Shimotakahara A, Yamataka A, Yanai T, Kobayashi H, Okazaki T, Lane GJ, Miyano T. Roux-en-Y hepaticojejunostomy or hepaticoduodenostomy for biliary reconstruction during the surgical treatment of choledochal cyst: which is better? Pediatr Surg Int. 2005 Jan;21(1):5-7. http://dx.doi. 10.1007/s00383004-1252-1

7. Todani T, Watanabe Y, Narusue M, Tabuchi K, Okajima K. Congenital bile duct cysts: classification, operative procedures, and review of thirty seven cases including cancer arising from choledochal cyst. Am J Surg. 1977;134:263-9.

8. Todani T, Watanabe Y, Toki A, Urushihara N, Sato Y. Reoperation for congenital choledochal cyst. Ann Surg. 1988 Feb; 207(2):142-7.

9. Lee SC, Kim HY, Jung SE, Park KW, Kim WK. Is excision of a choledochal cyst in the neonatal period necessary? J Pediatr Surg. 2006 Dec;41(12):1984-6. http://dx.doi.org/10.1016/j. jpedsurg.2006.08.023

10. Li MJ, Feng JX, Jin QF. Early complications after excision with hepaticoenterostomy for infants and children with choledochal cysts. Hepatobiliary Pancreat Dis Int. 2002 May;1(2):281-4.

11. Yamataka A, Ohshiro K, Okada Y, Hosoda Y, Fujiwara T, Kohno S, Sunagawa M, Futagawa S, Sakakibara N, Miyano T. Complications after cyst excision with hepaticoenterostomy for choledochal cysts and their surgical management in children versus adults. J Pediatr Surg. 1997 Jul;32(7):1097-102.

12. Miyano T, Yamataka A, Kato Y, Segawa O, Lane G, Takamizawa S, Kohno S, Fujiwara T. Hepaticoenterostomy after excision of choledochal cyst in children: a 30-year experience with 180 cases. J Pediatr Surg. 1996 Oct;31(10):1417-21. 


\section{Sažetak}

\section{KAKO TERAPIJSKI POSTUPITI KOD CISTE KOLEDOKUSA?}

\section{Marušić, A. Dominković, Ž. Belošić Halle, R. Troskot Peric, I. Zoričić, D. Vukušić i A. M. Liberati Čizmek}

Opisan je slučaj bilijarne ciste tip II. koja je u naše bolesnice usprkos svojoj a priori dobroćudnoj naravi bila uzrokom brojnih komplikacija poput ponavljajućih kolangitisa i pankreatitisa s posljedičnom jetrenom cirozom te potencijalnom opasnošću od perforacije koledohocele. Usprkos svojoj dobroćudnoj naravi bilijarne/koledohalne ciste mogu uzrokovati mnogobrojne poremećaje poput kolestaze s kolangitisom, pankreatitisom i bilijarnom sepsom, a s obzirom na kroničnu upalu bilijarnog sustava mogu pogodovati i nastanku kolangiokarcinoma. Iz primjera naše bolesnice može se zaključiti kako u određenom broju slučajeva čak i ovaj tip bilijarne ciste (prema dostupnoj literaturi najmanje zastupljen i najbenigniji tip) treba razmotriti s kirurškog aspekta, jednako kao i bilijarnu cistu tip I. Naime, pravodobna resekcija odnosno ekscizija bilijarne ciste u naše bolesnice svakako bi smanjila gore spomenute komplikacije, a isto tako i opetovane invazivne dijagnostičke i kirurške zahvate kojima je bolesnica bila višestruko podvrgnuta.

Ključne riječi: Žučni trakt, bolesti - terapija; Kolangitis; Pankreatitis; Žučni vodovi-kirurgija; Prikazi slučaja 